OPEN ACCESS

Edited by:

Heidi L. Hallman,

University of Kansas, United States

Reviewed by:

Jodi Nickel,

Mount Royal University, Canada

Paul Betts,

University of Winnipeg, Canada

${ }^{*}$ Correspondence:

Pennie L. Gray

pgray1@iwu.edu

Specialty section:

This article was submitted to

Teacher Education,

a section of the journal

Frontiers in Education

Received: 07 February 2020

Accepted: 07 May 2020

Published: 05 June 2020

Citation:

Gray PL and Seiki S (2020) Institutional

Performativity Pressure and First-Year

Teachers. Front. Educ. 5:71

doi: 10.3389/feduc.2020.00071

\section{Institutional Performativity Pressure and First-Year Teachers}

\author{
Pennie L. Gray ${ }^{1 *}$ and Sumer Seiki ${ }^{2}$ \\ ${ }^{1}$ Department of Education Studies, Illinois Wesleyan University, Bloomington, IL, United States, ${ }^{2}$ Teacher Education \\ Department, University of San Francisco, San Francisco, CA, United States
}

The challenges of negotiating the first year of teaching is something that concerns not only nascent teachers, but also many teacher educators and school administrators (Dugas, 2016). This case study of two beginning teachers explores the ways these teachers navigated the pressures of institutional performativity. Interviews reveal that both teachers' identities were impacted by external data-driven learning measures. The first-year teachers wrestled with the quantifiable data that served as evidence of their merit. At times, these external expectations created a crisis in values in that the beginning teachers felt they must abandon what they knew to be effective practices and instead adopt their school norms or approaches that would meet these external demands. This research points to the ways teacher educators and school administrators must work alongside beginning teachers to be a catalyst for systemic change toward student-centered learning and away from an over emphasis on student data driving perceptions of teacher merit.

Keywords: teacher education, institutional performativity pressure, induction, first-year teachers, case study

\section{INTRODUCTION}

During teacher preparation programs, teacher candidates often imagine who they will be as an educator. They may envision themselves as compassionate and competent, firm but loving, effective yet engaging, in other words, an idealized version of themselves. Unfortunately, these nascent teachers must reconcile this ideal teaching self with the realities and challenges of actual full-time teaching. Not only do beginning teachers have sole responsibility for their classroom and students for the first time, but they must also find a way to work effectively with the other teachers and staff in their new schools while negotiating the institutional pressures present in the school system.

Part of the challenge of taking on their first classroom involves a type of identity crisis for many beginning teachers. As (Craig, 2014) noted in her case study, beginning teachers struggled to resolve the tension between the identity they wanted for themselves and the "visions of teaching perpetuated and enforced by those in charge of [the] school and school district" (p. 82). This struggle was one reason Dugas (2016) issued a call not simply to talk about identity issues as a concept with beginning teachers, but also to help them become "aware of their own identity and identity processes" (p. 27). Without a clear sense of oneself as a teacher, beginning teachers are more vulnerable and likely to acquiesce to the status quo, leaving behind their idealized selves in favor of the existing system. In this case study we explore two first-year teachers' experiences as they navigate and form their new teacher identity. 


\section{THEORETICAL FRAMEWORK}

As Erickson explained, an individual's identity formation is a process of determining individual preferences, committing to a set of goals, standards, and values, and eventually accomplishing individuation (Good and Adams, 2008). Identity is not a final destination in an individual's life, but rather a process. Part of the process of identity formation is internal; however there are also external factors that influence an individual's identity, including relationships and interactions with cultural practices and institutional systems. For many beginning teachers, teaching is a deeply personal part of their identity. In essence, teaching is "not only a job but an expression of an inner ambition and moral conviction that defines the self" (Bullough and Pinnegar, 2009, p. 243). Hence the first year of teaching is a critical part of the path first-year teachers walk in their identity formation.

However, complicating this transition across the "threshold" (Vonk and Schras, 1987) of teaching are the mixed messages beginning teachers receive. As Flores and Day (2006) aptly note, beginning teachers face conflicting perspectives, beliefs, and practices concerning the nature of teaching and learning upon their entrance to the profession. Whereas, teacher preparation programs espouse relatively consistent beliefs and perspectives about the nature of teaching and learning, individual schools may conversely house teachers who embody a wide range of perspectives and beliefs, which they have cultivated over the course of their careers. Flores and Day refer to this encounter with so many different perspectives as a "reality shock" for nascent teachers (p. 219). This reality shock brought on by "negative school contexts and cultures" further results in a destabilization of what the beginning teachers thought it meant to be a teacher (p. 230). In fact, according to Flores and Day, many beginning teachers become less creative and more routine in their teaching practices (p. 230).

Likewise, Pillen et al. (2013) found that beginning teachers felt a tension between their personal beliefs about teaching and the professional demands of education (p. 86). These felt tensions were "accompanied by negative emotions, like feeling helpless and angry or being aware of shortcomings" (p. 87). Indeed, teachers do not operate in a vacuum; they are part of a broad educational context, and this context can be confounding for beginning teachers. As Smagorinsky et al. (2004) note, teachers are subject to "a community's vision of education, a school's mission toward realizing it, a curriculum through which to implement it, administrators invested in enforcing it, colleagues who help establish it, students who have been socialized to participate in it, and other relationships" (p. 9).

Thus, as first-year teachers attempt to construct their identities, they may encounter some unexpected challenges. Broemmel and Swaggerty (2017) found that some beginning teachers, in spite of receiving high ratings on their teaching, "consistently wrestled with following the path paved with their own knowledge and beliefs or just giving in to the pressures of conformity" (p. 49). This complexity of beginning teacher induction and the struggle to remain true to their own beliefs has been articulated as a struggle between social fear and professional fear and is part of the identity formation process. According to Broemmel and Swaggerty:

(Beginning teachers feel pressure to) abandon what is right for students out of fear-both social fear that if they go their own way and are successful, they will either make their colleagues look bad or they will appear arrogant in the process and professional fear that if they go their own way and fail, not only will they fail their students, but they may lose their jobs (p. 50).

The decisions beginning teachers must make are indeed fraught and carry significant consequences not only for their first year of teaching, but perhaps for many years to come as they solidify their teaching identities. Given these induction challenges and what is at stake, it is predictable that new teachers feel somewhat pressured and fearful; they perhaps become less idealistic and align "their expectations with their new colleagues" (Dassa and Nichols, 2019, p. 157). Beginning teachers may choose the path that is safest, at least for the time being. They may go along with what is expected of them, hoping that once they are established through tenure, they will approach their classrooms in a way similar to their idealized notions of teaching. These new teacher identity negotiations are formative and vulnerable to external pressures.

Influenced by identity formation is the concept of agency. Holland et al. (2001) defined agency as the actualized capacity of people to act upon the world. That capacity is the power of the individual to act strategically in the circumstances in which they live and to perpetuate and redefine their world or relationships. Thus, agency allows individuals to use past habits or meaningful experiences in order to overcome rigid structures or barriers. In this sense, identity is not a fixed construct pre-determined by the past, but a dynamic construct in which past and present converge. It is also a process through which individuals, at least in a small way, have the power to act upon and sculpt the world in which they live. The flexibility of identity through this continuous dialogic practice of responding to and addressing others allows for the individual to hope for the future (Vitanova, 2004), even during stressful or challenging times in teaching. Teacher agency, then, manifests through teachers' decisions and actions that support their identities and values (Brunetti and Marston, 2018, p. 12).

An external challenge experienced acutely by beginning teachers is the focus on student outcomes and the ongoing collection of high stakes student assessment data which has reshaped the function of schools and teachers (Walker, 2014). High stakes testing means that test scores are used to punish or reward classroom teachers and even their schools. A National Education Association survey revealed high stakes testing in the United States is used to punish schools through financial sanctions contributing to the phenomenon of nearly half of all teachers considering leaving the profession (Walker). Indeed, this focus on data has changed the very definition of a teacher (Walker). Lewis and Holloway (2018) conclude that the expression of one's effectiveness as an educator has been recast using the mold of data (p. 4), with the worth of a teacher measured against assessable student outcomes. Teachers are confronted with a "baffling array of figures, indicators, comparisons and forms of competition" (Ball, 2003, p. 220), 
which undermine the stability, self-worth, and contentment experienced by teachers. Even more, "performance targets... regulate teachers' professional conduct by introducing invisible means of social control through data generating monitoring systems" (Singh, 2018, p. 491). Because teachers enter the field with idealized notions of who and what they should be as teachers-their teacher identity-these external demands send them into a crisis of values, causing them to question which aspects of their work are valued, how to prioritize efforts, and whether teachers are still effective if their students have low test scores (Ball, 2003, p. 220). Given these pressures, it is clear "just how complex it can be... to enact one's vision as an educator and to demonstrate a sense of agency" (Vaughn, 2013, p. 131).

Beyond the added pressure of high stakes testing, the United States' institutional focus on testing outcomes can set up new teachers to question their beliefs and cause them to move away from effective pedagogy and instead focus on test scores (Walker, 2014). This shift toward quantifiable outcomes changes teachers' identities and how they see themselves. Put succinctly, when policy makers "promote institutional and social practices that make teachers fearful and force them to teach against their ideals and contrary to their practical wisdom" (Bullough and Pinnegar, 2009, p. 243), it is not just teachers who fail, but also schools.

The need to produce data and evidence to prove one's worth as an educator is a United States phenomenon we are calling institutional performativity pressure. For our purposes, we define an institution as a formal system, in this case, an educational system, that is dictated by laws, common expectations, and accepted practices. An institution can be local, such as an individual school district, or much larger, such as a state school system, or larger still, such as a national school system. An institution holds expectations of the people who function within it, with some of these expectations tacit and others explicit.

While the concept of performativity has been taken up in a range of fields, we turn to Ball (2003) to frame this concept within the educational landscape. According to Ball:

Performativity is a technology, a culture and a mode of regulation that employs judgements, comparisons and displays as means of incentive, control, attrition and change based on rewards and sanctions (both material and symbolic). The performances (of individual subjects or organizations) serve as measures of productivity or output, or displays of "quality," or "moments" of promotion or inspection. As such they stand for, encapsulate or represent the worth, quality or value of an individual or organization within a field of judgement (p. 216).

Ball's conception of performativity emphasizes regulation, judgements, comparisons, rewards, and sanctions. It is relatively easy to see the correlations between Ball's definition of performativity and the everyday goings on in most schools: Curricula are regulated by state or national standards; Judgements are made about a teacher's effectiveness through regulated, quantitative teaching evaluations; Test score comparisons are made within a school, between schools, and even state-to-state, with much of this high stakes testing data available for public viewing on state education websites.
While there are few tangible incentives or rewards that teachers are promised if students' test scores are strong, there are most definitely sanctions for test scores that are weak. To wit, New York City has closed 91 of its public schools since 2002 due to low test scores, and the Chicago Public School district was slated to close 14 schools in 2018 alone for the same reason (Public School Review, August 6, 2018). With performativity the current emphasis in education, this expectation of performativity forces teachers to turn their own classroom practices into "a strategy for obtaining student compliance, just one more tool for raising test scores, and not an authentic expression of human connection" (Bullough and Pinnegar, 2009, p. 253).

Therefore, we define the concept of institutional performativity pressure as the external exertion of the expectation that teachers provide proof of their merit, often in the form of quantifiable test data. These external expectations create a crisis in values for teachers in that they may feel they must abandon what they know to be effective practices for their students and instead adopt practices or approaches that will meet these external, institutional demands. This abandonment of their beliefs weakens their agency and calls their identity into question.

In light of the institutional performativity pressures felt by many first-year teachers, it may be helpful to question how education arrived at its present state of espousing seemingly contradictory goals: the need for quantifiable data to prove student learning and the aspiration of meeting the needs of the whole child. Labaree (2005) offered insights into just this issue as he retraced the debate about education over the past hundred years. According to Labaree, the twentieth century brought a "struggle for control of American education" between the pedagogical progressives and the administrative progressives (p. 276). Pedagogical progressivism focused on needs-based instruction, learning to learn rather than learning content, and active, self-directed learning (p. 277). Through pedagogical progressivism, "community, cooperation, tolerance, justice, and democratic equality" were valued (p. 277). On the other hand, the administrative progressives emphasized "social efficiency" ( $p$. 281 ), which led to an effort to make schools run more efficiently, like a business. This philosophy resulted in an emphasis on "rigorous academic frameworks for the school curriculum, setting performance standards for students, and using high stakes testing to motivate students to learn the curriculum and teachers to teach it" (p. 277).

In this struggle for control of education it is not difficult to see which side won. As Labaree concluded, pedagogical progressivism is still touted in schools of education and has changed the way education is discussed, but administrative progressives won the struggle hands-down in terms of how schools function on a day-to-day basis. This outcome has led to a clear contradiction between what is said in education vs. what is enacted. This struggle is also reflected in United States federal policies and the No Child Left Behind (NCLB) Act, which tied federal funding to state performance on high stakes tests harming the most vulnerable student populations (Walker, 2014). Though the more recently enacted Every Student Succeeds Act removed federal penalties, the practice of punitive high stakes 
testing remains in place and reflects the modern resurgence of the historic administrative expediency struggle.

Given today's increased emphasis on quantifying teaching and learning, especially in the wake of NCLB high stakes testing and the lingering federal punitive policies, it is not surprising that schools carve out less space for collaboration and open sharing and instead focus on quantifiable outcomes like test scores. Tragically, the test scores are often a means of school funding (Walker, 2014). As Glazier et al. (2017) noted, schools "do not foster safe spaces for teachers to admit any weakness or struggle" (p. 12). Likewise, this unsafe environment reduces innovation in the classroom because if an idea or approach fails, much is at stake. Roberts-Holmes (2015) referred to the current transformation of education as the "datafication" of education (p. 302), a term that seems apt. In essence, teachers' work is constrained and shaped by performativity demands that arise from this institutional datafication of education.

It is within this educational context of institutional performativity pressure and the datafication of education that we situate this study. This study is likewise situated in Labaree's administrative progressive expediency. The primary question driving this study is: How do first-year teachers experience and respond to institutional performativity pressures? According to our findings, institutional performativity pressure can manifest in a variety of ways, but we will limit our discussion of this phenomenon to two separate but related areas: content teaching and learning, and assessment. We are interested in exploring the lived experience of beginning teachers who must navigate the treacherous waters of shaping themselves into the teachers they want to be in an environment that is somewhat hostile toward this goal.

\section{METHODS}

This case study research is part of a larger body of research on first-year teachers and the challenges they face as they enact classroom management strategies (Gray, 2019). At the onset of this research, Gray conducted semi-scripted interviews with sixteen participants, all of whom graduated from the same teacher education program and who secured teaching positions in an elementary or middle school classroom. The interviews were conducted in the late fall of the teachers' first year of teaching. The timing of these interviews was purposeful in that Gray wanted to capture the experience of the teachers after the year was already well underway but before the teachers had further solidified their teaching identities at the end of the year. Each audio recorded interview lasted from $45 \mathrm{~min}$ to an hour and a half. After the interviews were completed, they were transcribed verbatim for individual and collective analysis.

As Gray examined the data, she noticed trends not only related to classroom management, the original focus of the research, but also related to other challenges the first-year teachers were facing. After noting these initial trends in the data, Gray sought the collaboration and consultation of her colleague, Seiki. With participants' permission and approval through her Institutional Review Board, Gray invited Seiki to join her as she analyzed five specific cases that featured explicit discussions of the pressures felt by the first-year teachers. This collaboration helped ensure that the subjectivity of Gray, a former professor of the participants, was mitigated through Seiki's interpretation of the data. This case study research is classified as emergent in its design: the focus of the original research shifted "in response to a growing understanding of the case" and "a change in the emphasis" (Simons, 2009, p. 31) of the research from classroom management to institutional performativity pressure.

Gray and Seiki read the five case study data sets individually to glean broad trends related to the ways in which the firstyear teachers interacted with the structure of the school system broadly defined. Initial trends in the data yielded a number of preliminary conclusions related to how the beginning teachers made decisions about their classrooms. The researchers met weekly to compare their observations of the data and then to collaboratively code each individual case study. This type of collaboration served to create inter-subjective reliability (Simons, 2009 , p. 130) to confirm each researcher's interpretation of the data.

Once the line-by-line coding of each transcription was complete, Gray contacted participants via email to inquire about their experience with the phenomenon of institutional performativity pressure. This second communication came at the end of the school year. The authors contacted the participants again because this phenomenon was not part of the original interview protocol and emerged organically from the data. Gray and Seiki wanted the participants to comment explicitly on this topic to gauge whether the conclusions they drew from their coding and analysis of the case studies were accurate. This followup email served as an initial respondent validation (Simons, 2009, p. 131) to ensure that the data analysis and preliminary findings were accurate. A number of the participants sent lengthy emails in response to the email query citing even more examples of the ways in which they experienced institutional performativity pressure during their first year of teaching. These additional examples were then used to supplement the existing data from the interviews and to confirm that the struggles they experienced in the fall were still present at the end of the year.

Although five participants' interviews were identified for analysis, we have chosen two upon which to focus. This decision is purposeful because these two participants capture and exemplify the range of experiences noted in the data. These two first-year teachers were best able to articulate how their entry into the profession had been shaped by the pressures they felt. In both instances, the first-year teachers were considered highly successful, both during their teacher preparation program and in their first year of teaching. They entered the teaching profession under similar circumstances as noted below. Therefore, these two participants were chosen due to their success in their teacher preparation program, their success in their first year of teaching, and their ability and willingness to grapple with the very real pressures they felt during their induction year. By focusing closely on these two cases, we are better able to capture the full experience of these two educators and accurately reflect their situations (Simons, 2009, p. 128). Once the initial draft of this manuscript 
was complete, it was sent to the two identified participants for their responses. Both participants enthusiastically endorsed the findings of the manuscript and the way in which their experiences were represented and contextualized. This follow-up communication served as an additional respondent validation. Thus, the findings of this research have been triangulated through two rounds of respondent validation, through intersubjective reliability between the two researchers, and through its connection to existing theories, such as the datafication of education and performativity.

As previously stated, both participants graduated from and were licensed by the same teacher education program housed at a small liberal arts university in the Midwest. These two participants, Amelia and Shannon ${ }^{1}$, were both white female firstyear third-grade teachers who were teaching at similar schools. An examination of school statistics showed that both schools had mobility rates below 7 percent, and the yearly teacher retention was high at both schools (i.e., between 77 and 89 percent) ${ }^{2}$. Average class sizes were between twenty and twenty-one students at both schools, but the student to teacher ratio was slightly different, with Amelia's school district at a 15 to 1 ratio, and Shannon's district at an 18 to 1 ratio. The districts differed on teacher salary and per-student spending. Amelia's school spent $\sim \$ 9,500$ per student per year, whereas Shannon's school spent just over $\$ 6800$. This difference in per-student spending may be a attributed to a number of factors: $19 \%$ more teachers in Amelia's school district held a master's degree, meaning their pay was most likely higher; Amelia's school was situated in the suburb of a large city, and Shannon's school was situated in a smaller community in a rural area where the tax base and cost of living were lower; Amelia's school had a larger population of English Language Learners (18 vs. $3 \%$ ), which may have necessitated more resources and expenses.

Amelia and Shannon characterized their principals as supportive and understanding, and both indicated that they were comfortable going to their principals with their questions and concerns. Likewise, both first-year teachers characterized their colleagues as supportive and encouraging and regularly consulted with them about curricula and other classroom issues. Therefore, both schools and teaching environments were similar enough to conclude that Amelia and Shannon entered the teaching profession under comparable circumstances.

We note that this case study is not intended to point definitively to a particular solution or to cast blame or praise on any given school or school district; rather, it is intended to turn a spotlight on a "contemporary phenomenon within its real-life context" (Simons, 2009, p. 20). By illuminating the challenge of institutional performativity pressure, we hope to equip teacher education programs with insights that may shape their preparation of their students to navigate these challenging times in education.

\footnotetext{
${ }^{1}$ All names are pseudonyms.

${ }^{2}$ Data were gathered from the state's teacher licensing website which reports statistics about each school in the state.
}

\section{RESULTS}

In Shannon and Amelia's experience, the phenomenon of institutional performativity pressure manifested in two broad areas: content teaching and learning, and assessments. There is a clear permeability between the borders of these aspects of any classroom; neither stands alone but rather each are influenced reciprocally by the another. For this manuscript, however, we will address both areas separately for ease of understanding.

\section{Shannon}

Shannon was a strong student during her undergraduate teacher education program, adeptly balancing a rigorous curriculum and robust field placements with her commitment to university athletics. Her full-semester student teaching practicum was in a third grade classroom similar to her first full-time teaching position. Shannon felt supported during her student teaching practicum and worked with a cooperating teacher who was willing to give her the latitude to try new and innovative teaching approaches. At the completion of her teacher education program, Shannon was licensed as an elementary teacher with a reading teacher endorsement.

\section{Content Pressure}

As Shannon reflected on her content teaching for the first 2 months of school, she noticed that she rushed through some of the content to ensure that students were prepared for their mandated assessments. She said, "If I take a step back, was I rushing to get to the content? Could I have spent more time doing [the establishment of the classroom environment]? So, I think that's where I'm torn" (Field notes, October 17, 2018). As Shannon continued to reflect on the first part of the school year during the October interview, she mentioned that there were particular approaches to the content that she did not use but was going to start using now that the first quarter of the year was finished. She said that what she had been doing was "not working for my kids. It's not working for me, and it's not working for them" (Field notes, October 17, 2018). She continued, saying:

I love when things are so hands-on, and I've been so afraid to try it because I wanted to get everything done that I had to get done. So this second quarter I'm like, "They'll learn what they learn." I will teach them what they need to know, and if I do it in a more engaging way, let's see what happens (Field notes, October 17, 2018).

In spite of her goal of moving toward more engaging teaching approaches, Shannon acknowledged that she had concerns about staying current on the content. She said, "(In math), we're so far behind, and assessments are due" (Field notes, October 17, 2018). Shannon continued posing rhetorical questions, like "What does it matter if they (students) can't write it (a math equation) on a test if they can tell me?" (Field notes, October 17, 2018).

Clearly Shannon struggled between meeting the institutional expectations for content pacing and doing what she knew was right for students. The institutional performativity pressure was exerted through the requirement of expediency in content delivery, driven in part by looming assessments. This institutional performativity pressure impacted Shannon's teacher identity 
causing her to abandon teaching approaches that she knew to be effective in favor of approaches that moved students toward the content and assessment targets. Her questioning of her own teaching approaches was apparent and part of her identity negotiation process. Because her teacher preparation program emphasized the need to be responsive to students' needs and to alter the pacing of the curricula to ensure that students were able to learn the content, Shannon faced the dilemma of choosing to enact the pedagogy she had been taught or meeting the institutional demands of her school.

\section{Assessment Pressure}

Shannon shared many concerns about assessment pressures she felt in just the first 2 months of school, pressures that weighed heavily upon her. First, she had significant concerns about the validity of the test instruments and their usefulness to teachers. She said, "They don't test the true ability of our kids. The assessments... are not current with the curriculum" (Field notes, October 17, 2018). Nonetheless, Shannon felt that she must teach to the test because of time pressures and a lack of enriching curricular resources.

However, far more distressing to Shannon than the validity of the assessments was the effects the assessments were having on students. She said of the testing sessions, "I feel so bad. I just sit there and I watch their faces, and they just sit there and look at the test. They're like, 'I don't know anything,"' (Field notes, October $17,2018)$. She bemoaned the fact that, if she were working with students in small groups on the same content as that covered by the tests, they would know the correct answers, but the act of testing was causing the students to doubt themselves. Shannon's frustrations were evident as she said, "We're so obsessed with data. Data, data, data. Let's stop and think: How is this affecting our 8 years old children?" (Field notes, October 17, 2018). Shannon did attempt to mitigate the negative effects of the testing process by talking candidly with her students about the assessments telling them that she was required by her district to administer the tests (Field notes, October 17, 2018). She hoped that by telling students this, they would be less anxious about the test and that they would not become discouraged. In spite of her assurances, she said that even her gifted students were pushed to tears by the tests. According to Shannon, she and the other gradelevel teachers all felt pressured to administer assessments that were too difficult for the students. Said Shannon, "We are killing these kids right now" (October 17, 2018). Shannon's frustrations at being placed in this untenable situation were palpable.

Beyond the negative effects of testing on the students, Shannon felt tremendous institutional performativity pressure because of the way the assessment data might reflect on her skills as an educator. As she said, "These are my kids, so these are my data," (Field notes, October 17, 2018). The emotional toll of the assessments on Shannon was clear. In a follow-up email after the end of the school year, Shannon said:

I can't tell you how many times... I felt so much less than as a teacher because of how test scores turned out. I remember getting our winter (test) data back and sitting there sobbing as I only had $7 / 26$ children meet the "expectations" (Personal Communication, July 23, 2019).
Similar to many schools and school districts, Shannon's school represented test scores using different colored dots on a graph to indicate visually how well students in a class were performing on the assessments. As she poignantly described:

This little, stupid, dot ate me alive all stinking year because it was orange instead of purple like it should be. The stupid little dot tore me down as a teacher because I felt like I wasn't teaching the right things. Or I wasn't doing enough to meet their needs. Or that I wasn't choosing instructional strategies that were working for my students. I remember getting physically sick around the time that spring data was to roll around and we got the email that data were uploaded (Personal communication, July 23, 2019).

Shannon did note that her standing as a first-year teacher might have been a slight advantage because she felt she might not be held as accountable for the test scores since she was new to the school and new to teaching. Fortunately for Shannon, her students' test scores did improve by the end of the year. Shannon's reaction to the improved test scores: "Finally, I thought, I have proven myself" (Personal communication, July 23, 2019). However, Shannon was deeply saddened to realize that, in the moment she saw the improved test scores, she felt successful as an educator. Upon reflection, Shannon commented on the shame she felt about her students' earlier test scores and on what should matter in terms of successful teaching:

I spent many meetings where data were discussed with tearfilled eyes because I was SO ASHAMED. But what the data don't show is how much personal growth my students had made in my first year of teaching. I had a student go from refusing to enter my classroom to giving me hugs each and every day before and after school. I had students who were coined as aggressive and anger management students learn how to use coping mechanisms and deal with problems in such a mature way by the end of the year. I had a student who used to shut down and hide under desks learn how to advocate for himself and discuss his emotions. That is what I think is success in teaching, not the data (Personal communication, July 23, 2019, punctuation in original).

Shannon captured the effects of institutional performativity pressure on her identity negotiation as a teacher succinctly when she said, "We are willing to let dot colors (i.e., assessment data) determine the worth of a teacher" (Personal communication, July $23,2019)$. It should be noted that Shannon received an award at the end of the school year recognizing her strong performance as a beginning teacher, an honor she no doubt found bittersweet.

\section{Amelia}

Like Shannon, Amelia was an exceptional student during her undergraduate preparation and was licensed as an elementary teacher with a reading teacher endorsement. Amelia distinguished herself as an ambitious and innovative undergraduate student. She spearheaded a campus-wide event to create awareness about people with disabilities, an initiative that Amelia coordinated in response to content she learned through her teacher education program. Amelia also completed a minor in Spanish along with an internship at a middle school in Mexico as part of her university's teacher education program. Amelia student taught in a sixth grade classroom with a cooperating 
teacher who was highly adept at classroom management and who was willing to let Amelia try out hands-on interactive lessons.

\section{Content Pressure}

Amelia's greatest pressure was in regard to her no-homework policy and whether her policy was disadvantaging students' content preparation. Not surprisingly, this institutional performativity pressure came from the families of her students. Amelia explained that, at the school year's first open house, she told families that she would not be giving students homework besides the standing assignment to read a set amount of time every day from a book of the students' choice. She supported her no homework policy by sharing three points: not all students were able to complete homework; there was little evidence pointing to the benefits of homework; and she wanted students to spend time with their families rather than on homework. Amelia anticipated that families would be relieved to learn of her policy because they would be free from the perennial homework difficulties that plague many families. However, the response from some families was just the opposite. Amelia said, "That was not something I was prepared to receive push back for" (Field notes, October 12, 2018).

According to Amelia, some parents voiced their opposition to her policy through emails on the day following the open house. Said Amelia, "I got a ton of emails saying 'I don't agree with your homework policy"' (Field notes, October 12, 2018). Some families were concerned that not having regular homework would disadvantage their children and would prevent them from entering the gifted program that began in fourth grade. Amelia tried to quell the families' concerns with a follow up email to all families in which she reiterated her policy and agreed to send home review materials prior to a test. Still, two families remained vocal about their opposition to her homework policy. Amelia coped with this challenge to her policy by reminding herself that "they're not the voices of the masses; they're the people who speak the loudest" (Field notes, October 12, 2018). In spite of the brave face Amelia wore, this pressure from a few families created considerable angst for her. She said, "I felt so bad because I felt like I was displeasing so many. That was the hardest thing for me" (October 12, 2018). She added that while she did not want to displease these families, she still disagreed with them, saying, "You didn't go to school for education" (Field notes, October 12 , 2018). Here, Amelia was embracing her preparation for the profession of teaching and was owning her teacher identity. After receiving her principal's support, Amelia felt more comfortable standing by her policy.

Amelia's security in in her own identity and agency exemplified by her decisions in the face of such pressures was perhaps unusual in a first-year teacher, but she did receive some feedback from families that confirmed her decision about homework and buoyed her confidence. During parent-teacher conferences, many of the families expressed their appreciation for her homework policy, noting that in second grade, there was significantly more homework which created difficulties for the families and which, they believed, caused their children to dislike school. Hearing this from a number of families was a tremendous relief for Amelia. Amelia did decide to appease the two families who were pressuring her to give more homework by offering optional weekly worksheet packets from the fourth and fifth grade curricula. She was careful to frame these packets as optional, and she noted that the students of the families who asked for more homework did not avail themselves of these optional homework packets.

Amelia's experience exemplified the ways in which those associated with the institution of education - the stakeholdershave internalized some aspects of the datafication of education and a focus on content preparation over the development of the whole child. While Amelia did not mention whether these families were concerned with test scores or assessment data, it is possible that these concerns were on their minds in relation to Amelias homework policy. Whatever the case, Amelia felt tremendous pressure from these individuals to change her practices.

\section{Assessment Pressure}

Amelia also expressed concerned about the ways assessment scores were used to determine which students received interventions. Amelias school worked to meet the needs of students who were struggling academically by holding weekly evaluative meetings on the effectiveness of the provided interventions. One incident illustrates how deeply troubling some institutional decisions were for Amelia.

One of Amelia's students was struggling in reading, so she sought help and guidance from two of her colleagues and used the interventions she learned through her teacher education program to support the student. In spite of his struggles, this student's initial assessment scores from the fall were slightly too high to receive more intensive interventions. However, after a subsequent round of testing, the student's scores went down, making him eligible for more intensive interventions. Even though Amelia was disappointed that her own efforts with the student were failing, she was encouraged that now, with these lower scores, her student could get the help he needed.

Unfortunately, the school's intervention specialist declined to work with the student because his needs did not align with the other students with whom the specialist was working. The need for more intensive interventions fell to Amelia. Said Amelia, "I was crushed by this because he was struggling in class and on tests, but because his needs did not fit with the (intervention) group," he could not receive help (Personal communication, July 29, 2019). She continued saying, "It seemed like data was so important... until a moment arose where there was additional work to be done" (Personal communication, July 29, 2019). Amelia was instructed to work one-on-one with this student for 10-20 min per day, "which is challenging when you have twentyone other students to meet with. It kind of all fell back on me" (Personal communication, July 29, 2019).

Amelia's disillusionment about the integrity of the data-driven intervention process at her school was evident as was her frustration. She talked about how there were regular discussions about meeting the needs of the whole child, but that a strict adherence to data prevented the faculty and staff from doing so. She commented: 
It really does seem like there is a pressure in schools to perform well even when administration says they want to support the whole student. It seems like the data, at times, is only being used when it supports their vision of what they want at school (Personal communication, July 29, 2019).

She continued, "It seems like things are ALL about the data... I think it's hard on everyone because we want to be whole-student oriented, but 'society' says we need to be data driven" (Personal communication, July 29, 2019, punctuation in original). It appeared that Amelia was less concerned about her students' assessment data than she was about how those data were used in this case to disadvantage a student in need of support, and this particular situation was the catalyst for disillusionment for Amelia. While the outcome of this situation was discouraging, Amelia nonetheless showed some agency by advocating for her student and speaking out on his behalf.

\section{DISCUSSION}

It is within what Larabee refers to as the administrative progressives-designed school system that first-year teachers find themselves as they try to enact the identities they are cultivating. The new teachers' identities continue to develop as they interact dialogically with others, for "the self is never without the defining presence of the other" (Vitanova, 2004, p. 11). In these constant interactions with those around them "people tell others who they are, but even more important, they tell themselves and then try to act as though they are who they say they are" (Holland et al., 2001 , p. 3). For our purposes, we define the others with whom the first-year teachers interact not only in terms of fellow faculty and staff, but also in terms of other stakeholders like school board members, school administrators, and the students' families. We might also propose that the institution itself is an "other" with whom beginning teachers must negotiate their identities. The first-year teachers in this study had to make decisions about who they were, even while they were constrained by an institution that attempted to shape them by way of systemic data collection and pressure to conform. Shannon's agency was diminished when confronted with the school's emphasis on test scores. She began to question her identity and grapple with her own pedagogy in this constrained environment. Amelia exhibited strong agency in the face of challenges to her policy but was still confounded by the ways in which her school embodied an administrative progressive efficiency.

As Pillen et al. (2013) point out, beginning teachers often confront "professional identity tensions" (p. 86-87). However, while Pillen et al. classify these tensions into six categories or profiles, the experiences of Amelia and Shannon represent a more blended profile. These first-year teachers did struggle to find the balance between the support they wanted to give their students and the support they were actually able to give their students when held to the demands of the institution (p. 94), or what might be called "care related tensions" (p. 91). But their concerns transcended this category. They were concerned not only with the care they gave their students; they were also concerned with the systemic pressures they were facing, for these systemic pressures interfered with their best intentions and desires for their students. In essence, the system thwarted their goals to be the best teachers they could be.

At the core of the first-year teachers' frustrations was the way data impacted their classrooms and students, data that the system demanded of them. Our findings are supported by Walker (2014) who found that nearly half of all teachers considered leaving the profession due to the institutional pressures of standardized testing and its negative effects on their students, classrooms, and curricula. Nonetheless, both first-year teachers in this study did indeed remain hopeful in spite of the constraints placed upon them, akin to Walker's (2014) findings. Both reiterated their desires to be risk-takers in their classrooms but acknowledged that they did not always feel safe taking risks because of the pressures exerted upon them. They often doubted themselves and questioned their own practice yet clearly expressed their desire to align their actions with their beliefs. Through our analysis of the interview data, we noted a number of instances during which the first-year teachers appeared to be having internal dialogues about the external pressures they experienced, and these internal dialogues gave us a glimpse into what they were saying to themselves about themselves and their place in the institution of education. Our findings support Broemmel and Swaggerty's (2017) observations of novice teachers and the tensions they experience due to internal and external struggles. Hence, our study points to the ongoing continuation of these issues (Pillen et al., 2013) as well as highlights a need for better support for novice teachers in this area.

Because we chose to confine this study to only two firstyear teachers, there are limits to the conclusions that can be drawn. Common sense might tell us that the institutional performativity pressures experienced by these two first-year teachers are likewise felt among other educators, but more research on this phenomenon is required to draw this conclusion. Rather than offer specific solutions to the phenomenon of institutional performativity pressure, we instead issue a call for schools, school districts, states, and even the nation to reevaluate the existing dependency on and use of data. Not all learning is quantifiable, and data do not reflect or guarantee a teacher's effectiveness or worth. In fact, the unintended consequences of the data generation that characterizes education today include diminished teacher confidence, increased student anxiety, and heightened pressure from and on families. To truly lessen the effects of institutional performativity pressure, those who hold the power to make decisions must begin to question their own assumptions and beliefs about what qualifies as education.

Or better yet, the people who make decisions about education and what counts as effective education should change. In order for education as an institution to move away from its current practice of datafication, it must return to a state of pedagogical progressivism with an emphasis on the whole child. Steps to accomplish this might include removing punitive measures linked to test scores and providing unilateral institutional support for teachers during their induction years when they are most vulnerable to institutional performativity pressures. Additionally, we join Broemmel and Swaggerty's (2017) call to raise awareness of institutional performativity pressures during the first year of 
teacher preparation so that beginning teachers are aware of what they will face during their induction years.

Moreover, teachers need to be given back their agency and allowed to make institutional changes to benefit their students. We are doubtful that any educator would willingly put their students through the rigors of a testing and data-gathering regimen when that very regimen brings many students to tears. There are other ways of determining student needs, if we only trust teachers once again. We must ask ourselves: What would a teacher-run school look like? While this is an admittedly idealistic question, it is a question worth posing.

In fact, this research illuminates a tension that is ubiquitous in education: the tension between skepticism and idealism. The emphasis on student test scores and the collection of data to prove a teacher's worth reflects an inherent skepticism about teachers' effectiveness and ability to teach. The two teachers in this study are by no means the only teachers who feel doubted by the educational institution for which they work. Yet, they have remained in the profession, and more importantly, they remain committed to someday creating the idealistic classroom they imagined when they first decided to enter the teaching profession. If we are to err, we should err on the side of idealism.

In these difficult times, we turn to Greene (2005) for inspiration and guidance. It is our hope that some educators, especially new educators just entering the profession, "avoid giving way to purely compliant practice" (p. 78). Instead, it is our hope that new educators-indeed, all educators-start a movement, not to retain their freedoms as Greene promotes, but rather to regain the freedoms they have already lost. We believe in the strength and ability of teachers to push back against the existing "preoccupations with testing, measurement, standards, and the like" which cast children as "human resources... who can and should be molded" by way of data (Greene, 2000, p. 270).

Through this research and in the spirit of Maxine Greene, we use our imaginations to envision a world in which we do not currently live, but one that could be. Like Labaree, we issue a call to enter into the historic struggle and begin to reshape present practices, to answer the call to a greater ideal. Novice teachers bring us hope for what education can be, and if we can lessen

\section{REFERENCES}

Ball, S. J. (2003). The teacher's soul and the terror of performativity. J. Educ. Policy 18, 215-222. doi: 10.1080/0268093022000043065

Broemmel, A. D., and Swaggerty, E. A. (2017). "I've tried and I've died this year": first-year teachers reflect on literacy reform. New Educ. 13, 41-52. doi: 10.1080/1547688X.2015.1094712

Brunetti, G. J., and Marston, S. H. (2018). A trajectory of teacher development in early and mid-career. Teach. Teach. 24, 874-892. doi: 10.1080/13540602.2018.1490260

Bullough, R., and Pinnegar, S. (2009). The happiness of teaching (as eudaimonia): disciplinary knowledge and the threat of performativity. Teach. Teach. 15, 241-256. doi: 10.1080/135406009028 75324

Craig, C. J. (2014). From stories of staying to stories of leaving: a US beginning teacher's experience. J. Curr. Stud. 46, 81-115. doi: 10.1080/00220272.2013.797504 the institutional performativity pressure that thwarts their efforts, this goal might be realized. We end by repeating Greene's call for new educators:

It is an honor and a responsibility to be a teacher in such dark times - and to imagine, and to act on what we imagine, what we believe ought at last to be. The new educator can be an initiator of new beginnings; and to act at a beginning is to move toward possibilities, to live and teach in a world of incompleteness, of what we all are but are not yet (Greene, 2005, p. 80).

\section{DATA AVAILABILITY STATEMENT}

The datasets generated for this study are available on request to the corresponding author.

\section{ETHICS STATEMENT}

The studies involving human participants were reviewed and approved by Illinois Wesleyan University Institutional Review Board. The patients/participants provided their written informed consent to participate in this study. Written informed consent was obtained from the individual(s) for the publication of any potentially identifiable images or data included in this article.

\section{AUTHOR CONTRIBUTIONS}

PG contributed the conception, design, conducted the study, and wrote the first draft of the manuscript. SS examined the research methods, coanalyzed the data, and conceptualized the findings. Both authors contributed to the manuscript revision, read, and approved the submitted version.

\section{FUNDING}

The University of San Francisco, School of Education Joint Faculty Development Funds, and the Illinois Wesleyan University Artistic and Scholarly Development grant through the Mellon Center supported this research project.

Dassa, L., and Nichols, B. (2019). Self-efficacy or overconfidence? Comparing preservice teacher self-perceptions of their content knowledge and teaching abilities to the perceptions of their supervisors. New Educ. 15, 156-174. doi: 10.1080/1547688X.2019.1578447

Dugas, D. (2016). The ineffectiveness of "effective" management strategies: first year teachers, behavior management, and identity. Action Teach. Educ. 38, 18-33. doi: 10.1080/01626620.2015.1078754

Flores, M. A., and Day, C. (2006). Contexts which shape and reshape new teachers' identities: a multi-perspective study. Teach. Teach. Educ. 22, 219-232. doi: 10.1016/j.tate.2005.09.002

Glazier, J. A., Boyd, A., Hughes, K. B., Able, H., and Mallous, R. (2017). The elusive search for teacher collaboration. New Educ. 13, 3-21. doi: 10.1080/1547688X.2016.1144841

Good, M., and Adams, G. R. (2008). Linking academic social environments, egoidentity formation, ego virtues, and academic success. Adolescence 43, 221-236.

Gray, P. L. (2019). Mitigating the apprenticeship of observation. Teach. Educ. 1-20. doi: $10.1080 / 10476210.2019 .1631785$ 
Greene, M. (2000). Imagining futures: the public school and possibility. J. Curr. Stud. 32, 267-280. doi: 10.1080/002202700182754

Greene, M. (2005). Teaching in a moment of crisis: the spaces of imagination. New Educ. 1, 77-80. doi: 10.1080/15476880590934326

Holland, D., Lachicotte, W. L. Jr., Skinner, D., and Cain, C. (2001). Identity and Agency in Cultural Worlds. Cambridge, MA: Harvard University Press.

Labaree, D. F. (2005). Progressivism, schools, and schools of education: an American romance. Paedag. Hist. 41, 275-288. doi: 10.1080/0030923042000335583

Lewis, S., and Holloway, J. (2018). Datafying the teaching 'profession': remaking the professional teacher in the image of data. Camb. J. Educ. 49, 35-51. doi: 10.1080/0305764X.2018.1441373

Pillen, M. T., Den Brok, P. J., and Beijaard, D. (2013). Profiles and change in beginning teachers' professional identity tensions. Teach. Teach. Educ. 34, 84-97. doi: 10.1016/j.tate.2013.04.003

Roberts-Holmes, G. (2015). The 'datafication' of early years' pedagogy: 'If the teaching is good, the data should be good and if there's bad teaching, there is bad data.' J. Educ. Policy 30, 302-315. doi: 10.1080/02680939.2014.924561

Simons, H. (2009). Case Study Research in Practice. London: Sage Publications, Ltd. Singh, P. (2018). Performativity, affectivity, and pedagogic identities. Eur. Educ. Res. J. 17, 489-506. doi: 10.1177/1474904117726181

Smagorinsky, P., Cook, L. S., Moore, C., Jackson, A. Y., and Fry, P. G. (2004). Tensions in learning to teach: accommodation and the development of a teaching identity. J. Teach. Educ. 55, 8-24. doi: 10.1177/00224871032 60067
Vaughn, M. (2013). Examining teacher agency: why did les leave the building? New Educ. 9, 119-134. doi: 10.1080/1547688X.2013.778763

Vitanova, G. (2004). "Authoring the self in a non-native language: a dialogic approach to agency and subjectivity," in Dialogue with Bakhtin on Second and Foreign Language Learning: New Perspectives, eds J. K. Hall, G. Vitanova, and L. Marchenkova (Mahwah, NJ: Lawrence Erlbaum Associates, Inc.), 149-169. doi: 10.4324/9781410611659

Vonk, J. H. C., and Schras, G. A. (1987). From beginning to experienced teacher: a study of the professional development of teachers during their first four years of service. Eur. J. Teach. Educ. 10, 95-110. doi: 10.1080/0261976870100111

Walker, T. (2014). National education association survey: nearly half of teachers consider leaving profession due to standardized testing. Natl. Educ. Assoc. 16. Available online at: http://neatoday.org/2014/11/02/nea-survey-nearly-halfof-teachers-consider-leaving-profession-due-to-standardized-testing-2/

Conflict of Interest: The authors declare that the research was conducted in the absence of any commercial or financial relationships that could be construed as a potential conflict of interest.

Copyright (๑) 2020 Gray and Seiki. This is an open-access article distributed under the terms of the Creative Commons Attribution License (CC BY). The use, distribution or reproduction in other forums is permitted, provided the original author $(s)$ and the copyright owner(s) are credited and that the original publication in this journal is cited, in accordance with accepted academic practice. No use, distribution or reproduction is permitted which does not comply with these terms. 